\title{
TRADITIONAL USES, PHYTOCHEMISTRY AND PHARMACOLOGICAL ACTIVITIES OF PAPAVER SOMNIFERUM WITH SPECIAL REFERENCE OF UNANI MEDICINE: AN UPDATED REVIEW
}

\author{
Masihuddin ${ }^{1}$, M.A Jafri ${ }^{2}$, Aisha Siddiqui ${ }^{3 *}$, Shahid Chaudhary ${ }^{4}$ \\ ${ }^{1}$ PG Scholar, Department of Ilmul Advia, School of Unani Medical Education and Research; Jamia Hamdard, New Delhi. India \\ ${ }^{2}$ Professor, Department of Ilmul Advia, School of Unani Medical Education and Research; Jamia Hamdard, New Delhi. India \\ ${ }^{3}$ Assistant Professor, Department of Ilmul Advia, School of Unani Medical Education and Research; Jamia Hamdard, New Delhi. \\ India \\ ${ }^{4}$ Assistant Professor, Department of Ilmul Advia, School of Unani Medical Education and Research; Jamia Hamdard, New Delhi. \\ India
}

\begin{abstract}
Papaver somniferum commonly known as Khashkhash /Afyon, belongs to family Papaveraceae. It is one of those traditional plants, which have a long history of usage as medicine. The opium poppy (Papaver somniferum) produces some of the most widely used medicinal alkaloids like morphine, codeine, thebain and porphyroxine which are the most important component of this plant. Apart from these alkaloids, opium poppy produces approximately eighty alkaloids belonging to various tetrahydrobenzyl isoquinolinederived classes. It has been known for over a century that morphinan alkaloids accumulate in the latex of opium poppy. According to Unani literature, it possesses most important theurapeutic values as modern literature and research studies also prove its therapeutical importance. It is used as analgesic, narcotic, sedative, stimulant as well as nutritive, etc. It is also useful in headache, cough, insomnia, cardiac asthma, and biliary colic. In this paper we have provide a review on habitate, pharmacological actions, phytochemical with special refrence to Unani Medicine. In this review, an attempt is made to explore the complete information of Papaver somniferum including its phytochemistry and pharmacology.
\end{abstract}

Keywords: Khashkhash, Biliary colic, Alkaloid, phytochemistry.

Article Info: Received 12 Sep, 2018; Review Completed 10 Oct 2018; Accepted 10 Oct 2018; Available online 15 Oct 2018

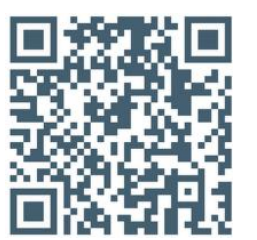

\section{Cite this article as:}

Masihuddin, Jafri MA, Siddiqui A, Chaudhary S, Traditional uses, phytochemistry and pharmacological activities of Papaver somniferum with special reference of Unani medicine: an updated review, Journal of Drug Delivery and Therapeutics. 2018; 8(5-s):110-1164 DOI: http://dx.doi.org/10.22270/iddt.v8i5-s.2069

\section{*Address for Correspondence:}

Aisha Siddiqui, Assistant Professor, Department of IImul Advia, School of Unani Medical Education and Research; Jamia Hamdard, New Delhi. India

\section{INTRODUCTION}

Over a period of times, the researchers have become more interested in finding out the potential of various drugs to treat diseases and to maintain the general health 1 . Herbal medicines are the unique gift of the nature as complementary to all the life in the world. Herbs are being use as medicine since the inception of life in the universe. Herbal drugs are derived from plants as whole or its part i.e. roots, stem, bark, leave, flower, fruit and seeds for the healing purposes ${ }^{2}$. Despite the emergence of new chemical drugs in contemporary medicine, the application of herbal remedies has not yet been declined.
Recently, interest in traditional medicine was revived by the WHO recommendations for the development of native knowledge and the use of alternative national medicine ${ }^{3}$. During the recent decades, chemical side effects have been identified and measures have been taken to overcome this problem. Thus, people again turned to natural products, especially in pharmaceutical industry. In recent years, medicine as well as health aspects are receiving special attention from the general public ${ }^{4}$. According to World Health Organization (WHO) reports that as many as $80 \%$ of the world's people depend on traditional medicine for their primary health care needs ${ }^{5}$. Although the use of medicinal herbs 
is not the only therapeutic method in traditional medicine, it is the basis of medical treatments ${ }^{6}$. A large number of herbal drugs are mentioned in Unany System of Medicine, one of them is Khashkash/Afyon (Papaver somniferum), belongs to family Papaveraceae. It is one of those traditional plants, which have a long history of usage as medicine. The word "opium" is of Greek (Unani) origin which is derived from "opos" (juice) and "opion" (poppy juice). Opium mostly postulated to came into Greece from Asia Minor and the ancient Greeks associated various divinities with opium, including Hypnos (sleep), Morpheus (dreams), Nyx (night) and Thanatos (the twin brother of Hypnos) (death). Opium is frequently mentioned in classical Unani literarure for its pain-relieving and sleep inducing action ${ }^{7}$. The opium poppy (Papaver somniferum) produces some of the most widely used medicinal alkaloids like morphine, codeine, thebain and porphyroxine which are the most important component of this plant. Morphine was the first plant alkaloid ever isolated in 1806 by a 22 year old German pharmacist, Friederich Wilhelm Adam Serturner. Morphine was extracted from the dried milky exudates, obtained from the capsule of Papaver somniferum. In 1839 the British successfully waged the Opium War with China to preserve its profitable opium trade. The surgeon William Halstead successfully "treated" a debilitative addiction to cocaine by switching to morphine ${ }^{8}$. According to Unani literature, it is used alone or in combination with other medicine as compound formulation like Itrifal Muqawwi Dimagh, Sharbat khashkhash, and khamir-e-khashkhash.etc ${ }^{9}$.

\section{TAXONOMICAL CLASSIFICATION Standard Report) ${ }^{10}$.}

\begin{tabular}{|l|l|}
\hline Kingdom & Plantae \\
\hline Subkingdom & Viridiplantae \\
\hline Infrakingdom & Streptophyta \\
\hline Superdivision & Embryophyta \\
\hline Division & Tracheophyta \\
\hline Subdivision & Spermatophyta \\
\hline Class & Magnoliopsida \\
\hline Superorder & Ranunculanae \\
\hline Order & Ranunculates \\
\hline Family & Papaveraceae \\
\hline Genus & Papaver L \\
\hline Species & Somniferum L \\
\hline
\end{tabular}

VERNACULAR NAMES ${ }^{9}, 11,12,13$.

\begin{tabular}{|l|l|}
\hline Language & Name \\
\hline English & Opium, Poppy, White poppy \\
\hline Urdu & Khashkash safaid \\
\hline Hindi & Afin, Khashkash, Afyun \\
\hline Arabic & Abunom, Afyiun \\
\hline Bengali & Pasto, Post \\
\hline Malyalam & Bungapion \\
\hline Greek & Agria \\
\hline Persian & Afiun, Khashkhash, Koknar \\
\hline Italian & Papavero, Papavero domestico \\
\hline Gujrati & Aphina \\
\hline Tamil & Abini \\
\hline
\end{tabular}

\section{HABITAT \& DISTRIBUTION}

It is an erect annual herb, about $60-120 \mathrm{~cm}$ height and is cultivated in many parts of the world and chiefly in Turkey, Asia minor, Persia, India, China, and Southeastern Europe. It is also grown and produced in Nepal, Assam, and Barma. It is produced in Bihar, Bangal, Banara, Central and Western India ${ }^{9,11,13}$.

\section{MORPHOLOGY}

\section{Macroscopic:}

The Seeds of Papaver somniferum Linn are dried, white, grey or grayish black in colour, sub-reniform and about $1.25 \mathrm{~mm}$ long. The surface is covered with polygonal reticulations about nine in length and five in width of seed, the hilum and micropyle are situated in a depression near one end. The embryo is curved and embedded in endosperm. Sweetish or oily in taste and unpleasant odour ${ }^{9,13}$.

\section{Microscopic:}

Sectional view of seed coat showed a single layer of epidermis which contains somewhat elongated, thick walled parenchymatous cells with thick cuticle on outer side. Below which the region is composed of polygonal to oval, thin walled parenchymatous cells. The epidermis of cotyledons is usually consisted of rectangular to oval, slightly thick walled parechymatous cells which possess yellowish brown contents. Rest of the part is made up of thin walled, hexagonal to polygonal parenchymatous cells, containing starch grains. The starch grains are oval to round in shape.

The sectional view of radical showed the epidermis composed of squarish parenchymatous cells. Aleurone grains are present in cortical region which consisted of many layers of thin walled, polygonal to oval parenchymatous cells ${ }^{9}$.

Parts Used: Fruits, Seeds and latex ${ }^{9,12}$

Temperament: (Mizaj): Seed. Cold ${ }^{2}$, Dry ${ }^{1},{ }^{9}$ Cold, ${ }^{14}$. White seed. Cold ${ }^{2}$, Moist ${ }^{1},{ }^{13}$

Black seed. Cold ${ }^{3}$, Dry ${ }^{2},{ }^{13}$

Dose (Miqdar-e-Khurak): Seed. 1-3g ${ }^{9}$

Post. 6.75 gm $^{15,16}$

Post. 1.75gm ${ }^{14}$ $\underset{15,16}{\text { Side Effects (Muzir Asrat): It has side effect on lungs }}$

Correctives (Musleh): Sugar, Asal (Honey) Mastagi (Pistacia lentiscus) ${ }^{15,16}$ Karfas (Pimpinella anisum) ${ }^{16}$

Substitutes (Badal): Tukhm-e-Kahu (Lactuca sativa Linn) ${ }^{16}$

\section{Compound Formulations (Murakkabat):}

Sharbat-e-Khashkhas, Laooq-e-Khashkhash, Itrifal Muqawwi-e-Dimagh, Roghan-e-Kishneez, Habb-eShaheeqa, Khameera-e-Khashkhash, Laboob barid ${ }^{9}$ 


\section{PHARMACOLOGICAL ACTIONS: (In Unani)}

\section{Actions of Seed:}

$>$ Mukhaddir (Anaesthetic) ${ }^{9}$

$>$ Qabiz (Constipative) ${ }^{9,11}$

$>$ Munawwim (Sedative/Hypnotics) ${ }^{9,14}$

> Muqawwi bah (Aphrodisiac) ${ }^{9,11}$

> Muqawwi Dimagh (Brain tonic) ${ }^{9,13}$

$>$ Mulattif(Demulcent) ${ }^{12,13}$

$>$ Mughazzi (Nutritive) ${ }^{12,13}$

$>$ Habis (Mild Astringent/ Retentive) ${ }^{13}$

$>$ Musakkin alam (Antianalgesic) ${ }^{14}$

\section{Actions of Fruit:}

$>$ Muzaf-e-bah (Anaphrodisiac) ${ }^{11}$

$>$ Moharrik baah (Sexual stimulant) ${ }^{11}$

$>$ Muqawwi Badan (Body tonic) ${ }^{11}$

$>\operatorname{Hazim}$ (Digestive) ${ }^{11}$.

> Munawwim (Sedative/Hypnotics) ${ }^{11,13,14}$

$>$ Muarriqu (Soporific) ${ }^{13}$

$>$ Mudir (Diuretic) ${ }^{11}$

$>$ Habis (Stringent) ${ }^{11,13}$

$>$ Musakkin alam (Antianalgesic) ${ }^{14}$

\section{THERAPEUTIC USES (IN UNANI)}

\section{Uses of Seed}

$>$ Ishaal (Diarrhoea) ${ }^{9,11,13}$

$>$ Zaheer (Dysentry) 9,11,13

$>$ Nazla (Catarrh/influenza) ${ }^{9}$

$>$ Sual (Cough) ${ }^{9,11,13}$

$>$ Asthma (Zeequnnafs) ${ }^{13}$

$>$ Sahar (Insomnia) ${ }^{13,14}$

$>$ Sual yabis (Dry cough) ${ }^{13,14}$

$>$ Sailanur Raham (Leucorrhoea) ${ }^{13,14}$

$>$ Ishaal safrawi (Bilious diarrhoea) ${ }^{14,}$

$>$ Hirqatul masana (Burning in bladder) ${ }^{14,}$

Uses of Fruits

$>$ Sual (Cough) ${ }^{11,13}$

$>\operatorname{Humma}(\text { Fever })^{11}$

$>$ Zaheer (Dysentry) ${ }^{11,13}$

$>$ Faqrud Dam (Anaemia) ${ }^{11}$

$>$ Ishaal (Diarrhoea) ${ }^{11,13}$

> Suda (Headache) ${ }^{11,13}$

Ashob-e-chasham (Conjunctivitis) ${ }^{14,}$

Ishaal safrawi (Bilious diarrhoea) ${ }^{14,}$

\section{CHEMICAL CONSTITUENTS}

Opium is valued for its alkaloids contents, the total alkaloid content varying from 5 to $25 \%$ (generally 20\%). A large number of alkaloids have been isolated from opium of which few known alkaloid are as follows:

\section{Morphine type:}

- Morphine ${ }^{12,13}$

- Codein ${ }^{12,13}$

- Neopine ${ }^{12,13}$

- Morphine (Pseudo, or oxymorphine) ${ }^{12,13}$

- Thebain $^{12,13}$

- Porphyroxine ${ }^{12,13}$

Phthalide isoquinolone type:

- Hydrocotarnine ${ }^{12,13}$

- Narcotoline ${ }^{12}$

- L-Narcotine : ${ }^{12}$

- Groscopine (dl-narcotine) ${ }^{12,13}$

- Oxynarcotine : ${ }^{12}$

- Narceine ${ }^{12,13}$

Benzyl isoquonoline type:

- Papaverine ${ }^{12,13}$.

- Xanthaline (Papaveraldine) $:{ }^{12}$.

- dl-Laudanine : ${ }^{12}$.

- Laudanine (Triotopine,l-laudanine) $:{ }^{12}$.

- Codamine ${ }^{12,13}$

- Laudamine ${ }^{12,13}$

- Laudanosine ${ }^{12,13}$

Cryptopine type:

- Protopine (macleyine, fumarine), ${ }^{12}$

- Cryptopine, ${ }^{12}$

Unknown Constitution:

- Aporeine ${ }^{12}$

- Rhoeadine $^{12}$

- Meconidine ${ }^{12}$.

- Papaveramine ${ }^{12,13}$

- Larthopine ${ }^{12,13}$

The ash of opium contains:

- Calcium, $7.79 \% \quad 9,12$

- Phosphorus, $7.52 \%{ }^{12}$

- Potassium, $28.04 \%{ }^{9,12}$

- Sudium, $0.78 \% \%^{9,12}$

- Magnisium, $0.69 \%{ }^{12}$ 
- Sulphur, $4.67 \% .^{12}$

- Iron, $\left(\mathrm{Fe}_{2} \mathrm{O}^{3}\right)+$ aluminium, $\left(\mathrm{Al}_{2} \mathrm{O}_{3}\right) 5.17 \%{ }^{12}$

- Corbon dioxide, $1.18 \%{ }^{12}$

- $\quad$ Sand and Silica, $20.13 \%{ }^{12}$

Opium contains several acids including, ${ }^{12}$

Meconic acid (up to 10\%), Lactic (1-2\%). Malic, Tartaric acid, Citric acid, Acetic acid, Succinic acid, Sulphuric acid, Phosphoric acid.

\section{Other constituents:}

Protein, Free amino acids, Caoutchous, (5-10\%). Brown wax (6-13.6\%). Volatile oil, Colouring matters, Dextrose (2.7-3.3\%). Pectin, Amonia, and three neutral principles, viz, meconin (opainyl), meconoisin and opoinin, and presence of the enzymes like, protease, oxydase, maltase, invertase, urease, and emulsion is also reported ${ }^{12}$

\section{PHARMACOLOGICAL STUDIES}

$>$ Antiallodynic activity ${ }^{17}$

> Analgesics activity $18,19,20,21,22,23,24,25,26,27$

$>$ Antitussive activity. ${ }^{28,29}$

$>$ Anti-diarrheal activity ${ }^{30,31}$

\section{REFERENCES}

1. Haider S, Batool Z, Haleem D. J, Nootropic and hypophagic effects following long term intake of almonds (Prunus amygdalus) in rats. Nutr Hosp. 2012; 27:2109-2115.

2. Dubey N. P, Basic principles of integrated medicine. $3^{\text {rd }}$ edition. World Association of Integrated Medicine. 2013. pp10.

3. Ameri A, Heydarirad G, Rezaeizadeh H, Choopani R, Ghobadi A, Gachkar A. Medicinal plants contain mucilage used in traditional Persian medicine (TPM). Pharm Biol, 2015; 53(4):615-623.

4. O. Kodad, R. Soclac company, Variability of Oil Content and of Major Fatty Acid Composition in Almond (Prunus amygdalus Batsch) and Its Relationship with Kernel Quality. J. Agric. Food Chem. 2008; 56:4096-4101.

5. Nejad A.S.M, Kamkar A, Giri A, Aziz A, Pourmahmoudi,Ethnobotany and folk medicinal uses of major trees and shrubs in Northern Iran. Journal of Medicinal Plants Research. 2013; 7(7):284-289, 17

6. Amiri M.S, Jabbarzadeh P, Akhondi M, An ethnobotanical survey of medicinal plants used by indigenous people in Zangelanlo district, Northeast Iran. Journal of Medicinal Plants Researc,. 2012; 6(5):749-753,

7. Schiff PL. Opium and Its Alkaloids. American Journal of Pharmaceutical Education, 2002 Vol. 66, Summer.

8. Haas LF. Papaver somniferum (opium poppy). Journal of Neurology, Neurosurgery, and Psychiatry, 1995; 58(4):402.

9. Anonymous. Standardisation of single drugs of unani medicine, $2^{\text {nd }}$ edition, CCRUM, Ministry of $\mathrm{H} \& \mathrm{FW}$, New Delhi, Govt. of India; 2006: part III, pp. 173-175.

10. ITIS https://web.archive.org

11. Kirtikar K.R, Basu B.D, I.C.S, Indian medicinal plants, $2^{\text {nd }}$ edition., International Book Distributers, Dehradun. 1987: Vol. II, pp. 124-127.

12. Anonymous. The Wealth of India, CSIR, New Delhi. 1997; 11:233-248.

13. Nadkarni K., The Indian Materia Medica, Bombay: A.K Nadkarni Publishers; 1989; 1:902-903.

14. Ibn Baitar, Aljame Li Mufradat al Advia wal Aghzia, (Urdu
Anti- smoking activity( Addiction) ${ }^{32,33}$

$>$ Antidepressant activity $34,35,36,37$

$>$ Anti-anxiety activity ${ }^{38}$

$>$ Bronchodilator activity. ${ }^{39,40}$

$>$ Antibacterial activity ${ }^{41}$

$>$ Narcotic activity ${ }^{42,43}$

\section{CONCLUSION}

From the time immemorial, it has been used for variety of ailments. Research in medicinal plants has gained a renewed focus recently. The discovery of natural alkaloids with promising biological activities have been demonstrated the significance of this plant drug. This review enriches our knowledge regarding the phytochemical as well as therapeutic values and pharmacological aspect used in Unani System of Medicine. Though Papaver somniferum has various medicinal applications, but it is need of hour to explore the more medicinal values at molecular level with the help of biotechnological tools and techniques. Further studies should be conducted to elucidate its mechanism of action in different diseases.

\section{CONFLICT OF INTEREST}

All authors have no conflict of interest.

translation). CCRUM, Dept. of AYUSH, Ministry of $\mathrm{H} \&$ FW, Govt. of India, New Delhi. YN, Vol.1I pp. 125-127.

15. Azam M.K, Muheet e azam (Urdu Translation by CCRUM), New Delhi: 61-65 Institutional Area; 2013: pp.477-479.

16. Ghani M.N. Khazaenul Advia.. Sheikh Muhammad Basheer and Sons, Lahore. YNM, Part II, Pp 513.

17. Brito A.M.S, Godin A.M, Augusto P.S.A, Menezes R.R, Melo S.F, Dutra MGMB, Costa SOAM, Goulart F.A, Rodrigues F.F, Ísis Morais M, Machado R.R, Coelho M.M, Antiallodynic activity of leflunomide is partially inhibited by naltrexone and glibenclamide and associated with reduced production of TNF- $\alpha$ and CXCL-1. Send to

Eur J Pharmacol, 2018; 818:17-25. doi: 10.1016/j.ejphar.2017.10.026.

18. Arner S, Meyerson BA, Lack of analgesic effect of opioids on neuropathic and idiopathic forms of pain, 1988. Pp 33:11-23.

19. Terashvili M, Wu H, Leitermann RJ, Sun H, Clithero AD, Tseng LF, Differential mechanisms of antianalgesia induced by endomorphin-1 and endomorphin-2 in the ventral periaqueductal gray of the rat. J Pharmacol Exp Ther. 2005, 312:1257-1265.

20. Sweitzer SM, Schubert P, and De Leo JA, Propentofylline, a glial modulating agent, exhibits antiallodynic properties in a rat model of neuropathic pain. JPharmacol Exp Ther. 2001; 297:1210-1217.

21. Colburn RW, Rickman AJ, DeLeo JA, The effects of site and type of nerve injury on spinal glial activation and neuropathic pain behavior. Exp Neurol, 1999; 157: 289-304.

22. Watkins LR, Milligan ED, and Maier SF Glial activation: a driving force for pathological pain. Trends Neurosci, 2001; 24:450-455.

23. Crain SM and Shen KF, Ultra-low concentrations of naloxone selectively antagonize excitatory effects of morphine on sensory neurons, thereby increasing its antinociceptive potency and attenuating tolerance/dependence during chronic cotreatment. Proc Natl Acad Sci USA, 1995; 92:10540-10544. 
24. Johnston IN, Westbrook RF, Inhibition of morphine analgesia by LPS: role of opioid and NMDA receptors and spinal glia. Behav Brain Res, Pain, 2005, 156:75-83.

25. Raghavendra V, Tanga F, Rutkowski MD, and DeLeo JA, Anti-hyperalgesic and morphine-sparing actions of propentofylline following peripheral nerve injury in rats: mechanistic implications of spinal glia and proinflammatory cytokines. Pain, 2002; 104:655-664.

26. McNicol ED, Midbari A, Eisenberg E. Opioids for neuropathic pain. Cochrane Database of Systematic Reviews 2013, Issue 8, Art, No.: CD006146. DOI, 10.1002/14651858.CD006146.pub2.

27. Vree T, Van Dongen, R, KoopmanKimenai P, "Codeine Analgesia is Due to Codeine-6-glucuronide, not Morphine." International Journal of Clinical Practice, 2000; 54(6):395.

28. Simera M., Poliacek J., and Jakus J, "Central Antitussive Effect of Codeine in the Anesthetized Rabbit, European Journal of Medical Research, 2010; 15:184-8.

29. Smith J, Owen E, Earis J, Woodcock A, Effect of Codeine on Objective Measurement of Cough in Chronic Obstructive Pulmonary Disease, Journal of Allergy and Clinical Immunology, 2006; 117(4):831-5.

30. Porreca F, Cowan A, Raffa R. B, and Tallarida, R. J, Ketazocines and Morphine: Effects on Gastrointestinal Transit after Central and Peripheral Administration, Life Sciences, 1983; 32(15):1785-90

31. Rozov-Ung, Mreyoud, A, Moore, J, Wilding, G. E, Khawam, E, Lackner, J. M, and Sitrin, M. D. Detection of Drug Effects on Gastric Emptying and Contractility Using a Wireless Motility Capsule, BMC Gastroenterology, 2014; 14(1): 2.

32. Hajek P, McRobbie H, Myers K. Efficacy of Cytisine in Helping Smokers Quit: Systematic Review and Metaanalysis, Thorax, 2013; 68 (11):1037-42.

33. West R, Zatonski W, Cedzynska M, Lewandowska D, Pazik J, Aveyard P, and Stapleton J, Placebo-Controlled Trial of Cytisine for Smoking Cessation, New England Journal of Medicine, 2011; 365(13):1193-200.
34. Agyapong V. I. O, Singh K, Savage M, Thekiso T. B, Finn, M., Farren, C. K., and McLoughlin, D. M, Use of CodeineContaining Medicines by Irish Psychiatric Inpatients before and after Regulatory Limitations on Their Supply, Irish Journal of Psychological Medicine, 2013; 30(01):7-12

35. Takita K., Herlenius E., Yamamoto Y., and Lindahl S. G, Effects of Neuroactive Substances on the Morphine-Induced Respiratory Depression; an in vitro Study, Brain Research, 2000; 884(1): 201-5

36. Clarke P. B., Fu D. S., Jakubovic A., Fibiger, H. C, Evidence that Mesolimbic Dopaminergic Activation Underlies the Locomotor Stimulant Action of Nicotine in Rats, Journal of Pharmacology and Experimental Therapeutics, 1988; 246(2):701-8.

37. Raghavendra V, Tanga F, Rutkowski MD, and DeLeo JA, Anti-hyperalgesic and morphine-sparing actions of propentofylline following peripheral nerve injury in rats: mechanistic implications of spinal glia and proinflammatory cytokines. Pain, 2002; 104:655-664.

38. Willette R.E., Analgesic agents, in Textbook of Organic Medicinal and Pharmaceutical Chemistry, 10th ed., (edit., Delgado, J.N. and Remers, W.A.), Lippincott-Raven, Philadelphia PA, 1998, pp. 687-71.

39. Schmeller T. and Wink M., "Utilization of alkaloids in modern medicine," in Alkaloids, (edit., Roberts, M.F. and Wink, M.), Plenum Press, New York NY, 1998, pp. 435-459.

40. Boselli G, Therapeutic activity of an association of a mucolytic drug and a bronchodilator agent in the treatment of respiratory inflammations, Minerva Med, 1973; 64(79):41283.

41. Chaudhry NMA, Tariq $P$, In vitro antibacterial activities of kalonji, cumin and poppy seed, Pak. J. Bot., 2008; 40(1):461-467,

42. Sofowora AE, Medicinal Plants and Traditional Medicines in Africa, $2^{\text {nd }}$ edition, Spectrum Books, Ibadan, Nigeria. p. 289

43. Okigbo N, Anuagasi CL, Amadi JE. Advances in selected medicinal and aromatic plants indigenous to Africa, Journal of Medicinal Plants Research, 2009; 3(2):086-095. 